WellBeing International

WBI Studies Repository

1997

\title{
Personality and Attitudes Toward the Treatment of Animals
}

Steve Mathews

Western Carolina University

Harold A. Herzog

Western Carolina University

Follow this and additional works at: https://www.wellbeingintlstudiesrepository.org/acwp_sata

Part of the Animal Studies Commons, Other Anthropology Commons, and the Social Psychology and Interaction Commons

\section{Recommended Citation}

Mathews, S., \& Herzog, H. A. (1997). Personality and attitudes toward the treatment of animals. Society \& Animals, 5(2), 169-175.

This material is brought to you for free and open access by WellBeing International. It has been accepted for inclusion by an authorized administrator of the WBI Studies Repository. For more information, please contact wbisr-info@wellbeingintl.org.

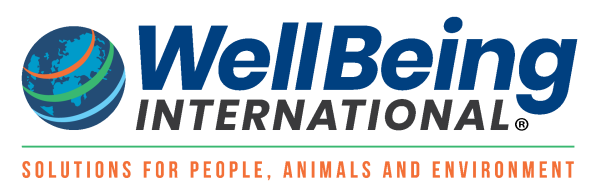




\title{
Personality and Attitudes toward the Treatment of Animals
}

Steve Mathews and Harold A. Herzog, Jr.

WESTERN CAROLINA UNIVERSITY

\begin{abstract}
The authors examined the relationship between personality and attitudes toward the treatment of animals by administering the Sixteen Personality Factor Inventory and the Animal Attitudes Scale to 99 college students. The personality scales were only weakly related to attitudes about animal welfare issues. Two personality factors, sensitivity and imaginativeness, were significantly correlated with attitudes towards animals. Gender and sensitivity explained $25 \%$ of the variance in attitudes, with most of the variance accounted for by gender.
\end{abstract}

People differ considerably in what they consider to be appropriate treatment of non- human animals. Some individuals believe that practices such as sport hunting, the consumption of animal flesh, and the use of non-human species in biomedical and psychological research are unjustified and cruel; in some cases, the very thought of these activities results in emotional distress. For others, these practices pose no particular moral problem and prompt no visceral revulsion. To what can we attribute these differences in perceptions about the use and treatment of other species?

Social scientists have only recently begun to explore the origins of attitudes towards non-human animals. There is a small but growing body of literature devoted to factors related to these attitudes. Variables known to influence individual differences in attitudes toward animals include gender (Driscoll, 1992; Gallup \& Beckstead, 1988; Herzog, Betchart \& Pittman, 1991; Hills, 1993; Kellert \& Berry, 1987); demographic variables such as educational level, geographic region, age, and race (Kellert, 1988); early experience with pets (Paul \& Serpell, 1993); beliefs about animal mentality (Herzog \& Galvin, 1997); and religious affiliation (Bowd \& Bowd, 1989).

Less is known about the relationship between fundamental personality traits and beliefs about the ethical treatment of other species. Broida, Tingley, Kimball and Miele (1993) recently examined the relationship between personality as measured by the Myers-Briggs Type Inventory (MBTI) and attitudes towards animal rights issues and vivisection as assessed by Takooshian's (1988) Animal Research Survey. Using over 1000 undergraduate college students as subjects, they found that individuals characterized by the MBTI as "intuitive and feeling types" were more supportive of animal experimentation than "sensate and thinking types."

The MBTI is a paper and pencil personality test closely tied to Jung's theory of psychological types. It is probably the most widely used personality assessment instrument designed for use with non-psychiatric populations (Devito, 1985), and there is a substantial body of empirical research based on the instrument. Despite its popularity and widespread use, however, the MBTI has largely been ignored or dismissed as a serious personality test by many traditional psychologists (Devito, 1985). For example, one widely used psychological assessment textbook (Cohen, Swerdlik \& Smith, 1992) barely mentions the MBTI. The reasons for the lack of attention to the test are unclear. Possible reasons include that the test is based on Jungian theory, which is not currently in vogue among psychologists, and that the MBTI was developed by individuals without training in psychometrics. In this study, we used a personality test which has wider acceptance among mainstream psychologists, the Sixteen Personality Factor Questionnaire, to examine the relationships between personality and attitudes toward the treatment of animals.

\section{Methods}

Forty-seven male and 52 female undergraduate psychology students from Western Carolina University participated in the study. The majority of the participants (95\%) ranged in age from 18 to 22, and most (87\%) were from rural or 
suburban areas of North Carolina. In groups of between 5 and 30, the subjects completed (in order) the Sixteen Personality Factor Questionnaire Form C, the Animal Attitude Scale, and a demographic questionnaire.

\section{The Sixteen Personality Factor Questionnaire}

The 16PF was developed by Raymond Cattell as a tool for assessing the "normal" personality, rather than a means of identifying patterns of psychopathology (Cattell, Eber, \& Tatsuoka, 1970). Cattell used factor analyses to reduce 4000 adjectives related to psychological differences to 16 basic factors. Four second- order factors were developed by factor-analyzing the correlations among the 16 scales. Construct validity of the 16PF factors is considered to be high, and the test questions are regarded as good measures of the personality traits that they purport to measure (Cattell et al., 1970). Form C, which consists of 105 items, is commonly used and has a wide research base. As Butcher (1985) wrote, "The 16PF is a venerable research instrument that has stood the test of time....There are few things in contemporary psychology that have been around as long and have attained the loyalty among its followers as the 16PF has managed to do" (p. 1392).

\section{Animal Attitude Scale}

The Animal Attitude Scale (AAS) assesses individual differences in attitudes toward the treatment of animals (Herzog et al., 1991). It is composed of 29 items which subjects rate on a five-point Likert scale (strongly agree to strongly disagree). Sample items include, "I do not think that there is anything wrong with using animals in medical research," "It is morally wrong to hunt wild animals just for sport," and "I would probably continue to use a product that I liked even though I know that its development caused pain to laboratory animals." The scale has been found to have high internal consistency (Cronbach's alpha $=.91)$. Factors known to influence scores include gender and sex-role orientation (Herzog et al., 1991), empathy (Galvin \& Herzog, 1994), personal moral philosophy (Galvin \& Herzog, 1992) and beliefs about the capacity of animals to experience mental states (Herzog \& Galvin, 1997).

\begin{tabular}{|c|c|c|}
\hline 16PF Factor & & $r$ \\
\hline Warmth & Reserved vs. Outgoing & -.048 \\
\hline Intelligence & Less intelligent vs. More intelligent & -.029 \\
\hline Emotional Stability & Easily annoyed vs. Calm & -.086 \\
\hline Dominance & Easily led vs. Aggressive & .016 \\
\hline Impulsvity & Restrained vs. Spontaneous & -.040 \\
\hline Conformity & Disregards rules vs. Rule-bound & -.019 \\
\hline Boldness & Hesitant vs. Unihibited & -.033 \\
\hline Sensitivity & Tough-minded vs. Tender-minded & $.276^{\star \star}$ \\
\hline Suspicious & Trusting vs. Suspicious & .108 \\
\hline Imaginative & Practical vs. Imaginative & $.203^{*}$ \\
\hline Shrewdness & Unpretentious vs. Calculating & -.039 \\
\hline Insecurity & Self-assured vs. Insecure & .114 \\
\hline Radicalism & Conservative vs. Liberal & .065 \\
\hline Self-sufficiency & Listens to others vs. Prefers own decisions & -.024 \\
\hline Self-discipline & Lax vs. Compulsive & .004 \\
\hline Tension & Relaxed vs. Tense & .052 \\
\hline${ }^{*} p<.05{ }^{* *} p<.01$ & & \\
\hline
\end{tabular}

\section{Results}

Pearson product-moment correlations between the personality factors measured by the 16PF and AAS scores are shown in Table 1. The correlations listed on the table are between the characteristic as described on the right side of 
the trait depiction and higher scores on the AAS. For example, a significant positive correlation between the first trait (warmth) would indicate that "outgoing" was associated with pro-animal attitudes, whereas a negative correlation would indicate that "reserved" was associated with pro-animal attitudes. Generally, the correlations between personality and attitudes toward the treatment of animals were low and not statistically significant. However, two of the personality dimensions, Sensitivity (Factor I) and Imaginative (Factor M) were significantly correlated with attitudes toward animal welfare. Our results also showed that female subjects had significantly higher AAS scores than male subjects $(t(97)=4.92, p<.001)$.

We used multiple regression to assess the relative importance of gender and personality variables in explaining individual differences in attitudes about animal welfare. Stepwise multiple regression was conducted with AAS scores entered as the dependent variable and the 16PF scores and gender as the independent variables. The analysis indicated that two variables, gender and sensitivity, were significant predictors of attitudes toward animals. Together they accounted for $24 \%$ of the variance in AAS scores (adjusted $\left.r^{2}=.239, F(2,96)=16.383, p<.000\right)$. Gender $(\beta=$ $.425, t=4.793, p<.0001)$ accounted more for the variance in AAS scores than sensitivity $(\beta=.227, t=2.564$, $p=.012$ ), accounting for $19.5 \%$ of the variance in all. Adding the $16 \mathrm{PF}$ sensitivity scale scores to the regression equation explained an additional $4 \%$ of variance in AAS scores.

\section{Discussion}

Among our subjects, measured differences in personality were only weakly related to attitudes toward the treatment of animals. Two of the sixteen Cattell scale dimensions - Sensitivity (Factor I) and Imaginative (Factor M) - were significantly correlated with AAS scale scores. Gender and sensitivity together explained about $25 \%$ of the variation in attitudes, with most of the variance accounted for by gender. The results of this study are similar to those found by Broida, Tingley, Kimball and Miele (1993) using the MBTI, reporting that individuals characterized as Intuitive- Feeling Types had the most positive attitudes toward animal welfare issues. Individuals categorized using the MBTI as intuitive types are said to make decisions based on general impressions and are less comfortable with routine, structured and mechanical approaches. Feeling types are believed to make decisions based on compassion and empathy (Broida et al., 1993). High scorers on the 16PF Sensitivity Factor have been similarly characterized as tender-minded, artistic, and intuitive. Individuals scoring high on the Imaginative Factor of the 16PF tend to be unconventional (Krug, 1981). Thus, although the 16PF and the MBTI were developed from quite different theoretical perspectives, the descriptions of traits associated with attitudes towards animals are similar.

Our data indicated that although a few personality traits were related to attitudes towards animal welfare, on the whole, personality (at least as measured by paper and pencil assessment devices) was not a major factor in determining the attitudes of a group of non-animal activists towards the treatment of other species. It is important to keep in mind that this study, like most research on attitudes about animals, was conducted using a sample of college students who were involved in the research as a course requirement. There have been a number of sociological/ psychological studies of animal activists (Herzog, 1993; Jamison \& Lunch, 1992; Jasper \& Nelkin, 1992; Pious, 1991; Shapiro, 1994; Sperling, 1988). However, in none of these investigations were measures of the personality traits of activists obtained. Our finding that personality is not highly related to attitudes toward animals may or may not hold for committed animal rights activists, who may have more extreme views on animal welfare issues. Clearly, more empirical research is needed before conclusions can be made about personality and the psychology of animal activism.

\section{References}

Bowd, A. C. \& Bowd, A. D. (1989). Attitudes toward the treatment of animals: A study of Christian groups in Australia. Anthrozoos, 3, 20.

Broida, J. P., Tingley, L., Kimball, R., \& Miele, J. (1993). Personality differences between pro and anti vivisectionists. Society and Animals, 1, 129-144.

Butcher, J. N. (1985). Review of Sixteen Personality Factor Questionnaire. In J. V. Mitchell I (Ed.) The ninth mental measurements yearbook (pp. 1391-1392). Lincoln: University of Nebraska Press. 
Cattell, R. B., Eber, H. W., \& Tatsuoka, M. M. (1970). Handbook for the Sixteen Personality Factor Questionnaire. Champaign, IL: Institute for Personality Ability Testing.

Cohen, R. J., Swerdlik, M. E. \& Smith, D. K. (1992). Psychological testing and assessment. Mountain View, CA: Mayfield Publishing.

Devito, A. J. (1985). Review of Myers-Briggs type indicator. In J. V. Mitchell (Ed.) The ninth mental measurements yearbook (1030-1032). Lincoln: University of Nebraska Press.

Driscoll, J. W. (1992). Attitudes toward animal use. Anthrozoos, 5(1),32-39. Gallup, G. G. \& Beckstead, J. W. (1988). Attitudes toward animal research. American Psychologist, 43, 474-476.

Galvin, S. \& Herzog, H. A., Jr. (1992). Ethical ideology, animal activism and attitudes toward the treatment of animals. Ethics \& Behavior, 2, 141-149.

Galvin, S. L. \& Herzog, H. A., Jr. (1994). Empathy, gender and attitudes toward the use of animals. Paper presented at the meeting of the Southeastern Psychological Association, New Orleans, LA.

Herzog, H. A., Jr. (1993). "The movement is my life": The psychology of animal rights activism. Journal of Social Issues, 46, 103-119.

Herzog, H. A., Jr., Betchart, N. S., \& Pittman, R. (1991). Sex role identity and attitudes toward animals. Anthrozoos, 4(3), 184-192.

Herzog, H. A., Jr. \& Galvin, S. (1997). Anthropomorphism, common sense, and animal awareness. In R.W. Mitchell \& N.S. Thompson (Eds.) Anthropomorphism, anecdotes, and animals (pp. 237-253). Albany, NY: SUNY Press.

Hills, A. M. (1993) The motivational bases of attitudes toward animals. Society \& Animals, 7,111-128.

Jamison, W. \& Lunch, W. (1992). The rights of animals, science policy and political activism. Science, Technology and Human Values, 17, 438-458.

Jasper, J. M. \& Nelkin, D. (1992). The animal rights crusade: The growth of amoral protest. New York: Free Press.

Kellert, S. R. (1988). Human-animal interactions: A review of American attitudes toward wild and domestic animals in the twentieth century. In A. N. Rowan (Ed.), Animals and people sharing the world (pp. 137-175). Hanover, NH: University Press of New England.

Kellert, S. R. \& Berry, J. K. (1987). Attitudes, knowledge, and behaviors towards wildlife as affected by gender. Wildlife Society Bulletin, 15, 363-371.

Krug, S. E. (1981). Interpreting 16PF profile patterns, Champaign, IL: Institute for Personality and Ability Testing.

Paul, E. \& Serpell, J. A. (1993) Childhood pet keeping and humane attitudes in young adulthood. Animal Welfare, 2, 321-337.

Plous, S. (1991). An attitude survey of animal rights activists. Psychological Science, 2. 194-196.

Shapiro, K. (1994). The caring sleuth: Portrait of an animal rights activist. Society \& Animals, 2, 145-165.

Sperling, S. (1988). Animal liberators: Research and morality. Berkeley: University of California Press.

Takooshian, H. (1988). Opinions on animal research: Scientists versus the public. PsyETA Bulletin, 7, 5-7. 